$\underset{\substack{\text { Member since } \\ \text { JM14482 }}}{2019}$

Dyskusje / polemiki / recenzje

Andrew Pudewa*

\title{
Choćby i niedoskonale: Nauki pobrane z trzydziestu lat nauczania ${ }^{1}$
}

\begin{abstract}
Abstrakt
Autor oryginału w eseistycznym stylu prezentuje siedem podstawowych zasad adekwatnego uprawiania edukacji, jakie płyną z jego osobistych nauczycielskich doświadczeń. Są to zasady zarówno pedeutologiczne, jak i pedagogiczne, w tym metodyczne oraz relacyjne, niestety rzadko w praktyce wdrażane.
\end{abstract}

Słowa kluczowe: edukacja, zasady, pedeutologia, pedagogika.

\section{However Imperfectly: Lessons Learned from Thirty Years of Teaching}

\begin{abstract}
The author presents, in essay style, seven basic principles of adequate education resulting from his personal teaching experience. These are both pedeutological and pedagogical principles, including methodological and relational ones, unfortunately rarely implemented in practice.
\end{abstract}

Keywords: education, principles, pedeutology, pedagogy.

* Institute for Excellence in Writing, Locust Grove, USA.

Artykuł otrzymano: 28.11.2020; akceptacja: 19.01.2021.

1 Tekst stanowi tłumaczenie na język polski artykułu autora pt. However Imperfectly: Lessons learned from thirty years of teaching opublikowanego w Institute for Excellence in Writing, Locust Grove, USA, https://iew.com/help-support/resources/articles/however-imperfectly-lessons-learned-thirty-yearsteaching). Autorem tłumaczenia na język polski jest Marek Budajczak. 
Jest mi trudno powiedzieć dokładnie, kiedy zacząłem uważać siebie za nauczyciela, ale pamiętam ów moment, kiedy rozpoczynałem swoją działalność jako niezależny instruktor nauki gry na skrzypcach, właściciel przedszkola, wychowawca i rodzic edukacji domowej (faceci na samozatrudnieniu muszą niekiedy imać się wielu zajęć, aby związać koniec z końcem). Było to jakieś trzydzieści lat temu. Tkwił w tym z pewnością pewien element przygody, rzecz jasna nie bez problemów i frustracji, jednak z olbrzymią ilością lekcji opanowanych po drodze. A chociaż większość mojego czasu spędzam obecnie, próbując systematyzować oraz przekazywać innym nauczycielom i rodzicom te techniczne sprawy, do których doszedłem w kwestii nauczania - zwłaszcza zaś nauczania pisania - to najcenniejszymi lekcjami są prawdopodobnie te, dotyczące filozofii, lub, jak nazywała je Pani Ingham, jedna z moich wspaniałych mentorów, „wartości niematerialne”. Spisuję je więc tutaj dla Was, Czytelników: Siedem lekcji wyniesionych z mojego trzydziestoletniego nauczania, sprawy, których być może warto byłoby mi nauczyć się wcześniej.

\section{Lekcja 1: Trudno jest nie robić swoim dzieciom tego, co zrobiono tobie}

Większość z nas chodziła do szkoły. Ja także, przez jedenaście lat, i do stosunkowo dobrych szkół publicznych z kilkoma pamiętnymi nauczycielami, znajdowanymi tu i ówdzie. W konsekwencji moje fundamentalne pojmowanie nauczania i edukacji wynika z moich własnych doświadczeń jako dorastającego ucznia. Później zostało ono wzmocnione wskutek trzech lat nader niezwyczajnego kształcenia dla nauczycieli w Instytucie Rozwijania Talentów, w Matsumoto, w Japonii. Ale w zasadniczej części, kiedy już zacząłem swoje nauczycielstwo, moje rozumienie szkoły wiązało się z tym, że winna się ona realizować za pomocą klas i poziomów kształcenia, podręczników i egzaminów, ocen i świadectw, które weryfikowane są dzięki standaryzowanym testom.

Zrządzeniem Opatrzności, szczęściem na początku mojej własnej kariery, zostałem obdarowany książką autorstwa Johna Taylora Gatto (1992), Nauczyciela Roku stanu Nowy Jork, który przez szesnaście lat nauczał angielskiego w ósmych klasach pewnej szkoły na Brooklynie. Już tytuł mnie ujął: Robiq z nas głupców: Ukryty program obowiązkowej edukacji ${ }^{1}$. To była niewielka książeczka, którą dosłownie połknąłem. Czytając ją, myślałem sobie: „No tak! To wyjaśnia, dlaczego sam jestem taki głupi!”. Tak się składa, że mniej więcej w tym właśnie czasie sam zacząłem zdawać sobie sprawę z tego, że jestem głęboko niewyedukowany i zastanawiałem się, dlaczego. Zawsze otrzymywałem dobre oceny. Czytałem książki. Poważnie traktowałem swoje powołanie nauczyciela muzyki. Gdy jednak przyswoiłem sobie książkę Pana Gatto, zdałem sobie sprawę, że moje własne dzieciństwo

\footnotetext{
1 J. T. Gatto (1992); wszystkie przypisy i uzupełnienia bibliograficzne pochodzą od tłumacza.
} 
było mniej związane z uczeniem się, a bardziej z rozgrywaniem obowiązkowej gry zwanej szkołą. Przy ponownej lekturze tego tekstu dotarła do mnie niewyraźna myśl, że oto może istnieć inny rodzaj edukacji i że może on być lepszy niż to, w czym dorastałem. Ale ponieważ Pan Gatto nie wyjaśnił zbyt wiele, jak to mogłoby wyglądać, byłem poniekąd zmuszony do samodzielnego poszukiwania $\mathrm{w}$ tym zakresie czegoś odmiennego.

Co oczywiste, mój trening w metodzie Suzukiego był odmienny. Shinichi Suzuki, założyciel Instytutu Rozwijania Talentów, wierzył, że każde dziecko może się nauczyć wszystkiego pod warunkiem, że zapewni mu się odpowiednie środowisko i metodę ${ }^{2}$. Wykorzystując muzykę jako studium przypadku, postanowił udowodnić to światu, a w wyniku jego pracy setki tysięcy - być może miliony - dzieci nauczyło się grać na skrzypcach lub innych instrumentach muzycznych niezwykle trudny repertuar i czyniły to tak, jakby było to całkiem łatwe. Jego celem nie było jednak stworzenie małych armii młodych skrzypków; jego celem było udowodnienie światu, że każde dziecko może się nauczyć wszystkiego. I dzieci to robiły. Robiły tak bez klas szkolnych z podziałem wiekowym, bez świadectw i ocen, bez gróźb i przymusu. Robiły to z radością i po mistrzowsku. Kiedy więc opuściłem Japonię, miałem nadzieję na kontynuowanie jego misji poprzez nauczanie muzyki i, jeśli byłoby to możliwe, przez stosowanie zasad rozwijania talentów również w innych obszarach tak nauczania, jak i uczenia się.

Przeczytawszy wywiad przeprowadzony przez Shinichi Suzukiego i Glenna Domana, wiedziałem już, jaki będzie mój następny krok: Instytuty Osiągania Ludzkiego Potencjału w Filadelfii ${ }^{3}$, gdzie przez trzy lata mieszkałem i uczyłem się jako młodszy pracownik. Pracując w klinice z dziećmi z urazami mózgu i ich rodzinami przez pół dnia, a przez drugą jego połowę jako praktykant w tamtejszej szkole dla dzieci utalentowanych, zdałem sobie jasno sprawę z tego, że każde dziecko uczy się inaczej i że najlepsze sposoby nauczania są bardzo, ale to bardzo różne od sposobu, w jaki mnie samego nauczano. Byłem młodym idealistą i w pełni wierzyłem w to, że zmieniamy świat dzięki prawdzie o dzieciach, ich mózgach, talentach oraz edukacji. Szkoła ta i jej metody były całkowicie niekonwencjonalne, stąd często myślałem sobie: „Szkoda, że nie miałem możności chodzenia do szkoły tego rodzaju - byłbym z niej zadowolony! Tak wiele by mi to dało!”

Jednak dopiero gdy opuściłem Filadelfię i zacząłem domową edukację swoich własnych dzieci, zdałem sobie sprawę, jak głęboko zakorzeniona była moja „szkolna" mentalność. Moja żona i ja karnie zamówiliśmy stertę podręczników z kolejnymi numerami na okładce i rozpoczęliśmy robienie „szkoły w domu”, kopiując ten sam system, co do którego byłem świadom, że nie chcemy być jego częścią. Moja żona, magister edukacji wczesnoszkolnej, obawiała się, że jeśli nie będziemy korzystać z podręczników dla poszczególnych klas i standaryzowanych testów, to

\footnotetext{
2 Talent Education Institute.

3 IAHP - The Institutes for the Achievement of Human Potential.
} 
nasze dzieci mogą zostać „w tyle”, co byłoby dla nas okropne. Stanęliśmy twarzą w twarz ze szkołą ze strachem (z wielkimi oczami), mimo iż wiedzieliśmy, że nie chcemy robić naszym dzieciom tego, co nam wyrządzono. Wkroczyliśmy tedy na długą ścieżkę odkrywania dostępnych opcji - szukania tego, co moglibyśmy realizować inaczej, i na jakie sposoby.

Często bywaliśmy podekscytowani, przy jednoczesnym niepokoju: A co gdybyśmy zawiedli nasze dzieci? Co by było, gdybyśmy nie przerobili wszystkich fundamentalnych zagadnień. A co, gdyby nasze dzieci okazały się niegotowymi, by pójść na studia? Nie były to lęki łatwe do pokonania. Jednak w miarę gdy spotykaliśmy ludzi o podobnej mentalności, jak czytaliśmy pomocne książki i pracowaliśmy nad dochowywaniem wierności naszym priorytetom, uciszanie tych lęków stało się tym łatwiejsze. Czasami wydawało mi się, jakbym był częścią pewnej wyimaginowanej grupy, którą można by nazwać Anonimowymi Szkołoholikami. „Cześć, mam na imię Andrew. Chodziłem do szkoły i nie chcę już myśleć według jej schematów..., nie chcę też robić moim dzieciom tego, co wyrządzono mnie samemu".

\section{Lekcja 2: Proces jest ważniejszy niż produkt}

Żyjemy w czymś, co niektórzy mogliby określić jako skrajnie kapitalistyczne środowisko, w którym prawie wszystko jest mierzone, porównywane i oceniane - często na podstawie swej opłacalności. Dzieje się tak wedle znanego porzekadła: „Nie dowiesz się, dopóki sam nie spróbujesz”. Jesteśmy stąd skwapliwi w natychmiastowym ocenianiu każdej rzeczy jako doskonałej, do przyjęcia albo nie do zaakceptowania. Niestety, kiedy ten rodzaj myślenia infekuje edukację, możemy łatwo popaść w nałóg oceniania różnych działań na podstawie efektów, jakie one generują, a następnie w nałóg „inżynieryjny” w celu wytwarzania produktu o potencjalnie wyższej jakości. A choć takie podejście może sprawdzić się w świecie przemysłu, w którym elementy składowe oraz materiały są statyczne i trwałe, ludzi - a zwłaszcza dzieci - nie da się tak kontrolować ani przewidywać ich działań. To, co widzę dziś całkiem wyraźnie, to fakt, że edukacja jest procesem, a jej efekty zaledwie pobocznymi artefaktami uczenia się, nie będąc ani jego wynikiem końcowym, ani nawet głównym celem.

Jest taka wspaniała scena w pewnym filmie, który chciałbym, aby wszyscy nauczyciele i rodzice mogli obejrzeć. Jakoś tak na początku Rzeki wspomnień, filmu opartego na autobiografii amerykańskiego pisarza Normana Macleana, mały Norman i jego młodszy brat Paul mają w swym domu (w wiejskiej części Montany), w ramach edukacji domowej, lekcję z ojcem, nader małomównym szkockim pastorem. Pierwszy z nich siedzi przy stole, pisząc jakieś opowiadanie czy wypracowanie. Zanosi je następnie ojcu, który wykreśla kilka rzeczy, robi kilka znaków i zwraca mu je z trzema słowami: „0 połowę krótsze”. Wróciwszy do swojego biurka, chłopiec przepisuje swoją pracę i zanosi ją jeszcze raz ojcu, który czyta 
tekst, umieszcza kolejne znaki i wręcza mu z poleceniem "Jeszcze raz. 0 połowę krócej". Poirytowany nieco dzieciak po raz trzeci przepisuje swoją pracę i ponownie przedstawia ją ojcu. Tym razem jednak odpowiedź jest inna. Ojciec czyta ten tekst, oddaje go chłopcu i mówi: „Dobrze. A teraz wyrzuć to do śmieci”. Chłopiec gniecie kartkę, wyrzuca do kosza na śmieci, chwyta swoją wędkę i wybiega frontowymi drzwiami, podczas gdy matka woła za nim: „Norman! Norman! Poczekaj na swojego brata!"

Wielokrotnie relacjonowałem tę scenę rodzicom oraz nauczycielom, i zawsze przy tej okazji fizycznie wręcz czułem, jak zgromadzeni wzdrygali się na słowa: „Wyrzuć to do śmieci”. Ależ on tak ciężko nad tym pracował! Czyż nie powinno się tej pracy zachować? Przynajmniej trzeba umieścić ją w portfolio dla udowodnienia, że coś zrobiliśmy? Ale, widzicie, lekcja ze strony tego ojca dotyczyła nie tylko ekonomii języka; chodziło o to, że to proces jest tu produktem, a sam wysiłek lekcyjny tego dnia jest wystarczający do uświadomienia tej prawdy. Chłopiec nie skończył się uczyć, ale zrobił postępy, stąd stwierdzenie: „Dobrze. A teraz wyrzuć to do śmieci", jest potwierdzeniem obu tych korzyści. Niestety dziś jesteśmy bezwarunkowo przywiązani do produktu, który możemy przypiąć do ściany lub powiesić na lodówce dla udokumentowania naszych starań. Obiektywnie rzecz biorąc, pisarstwo dziesięciolatka jest bezwartościowe więc w końcu i tak je wyrzucicie, więc dlaczego nie zaraz? To coś, co warto przemyśleć.

Kolejnym punktem w rozdziale traktującym o „wyższości procesu nad produktem" jest zrozumienie tego, że jeśli będziemy czekać, aż staniemy się bardzo dobrzy w nauczaniu danego przedmiotu, to możemy czekać tak długo, że w końcu nigdy tego nie spróbujemy. Jeden z moich ulubionych cytatów pochodzi od Gilberta K. Chestertona, który stwierdził: „Jeśli coś jest warte zrobienia, jest warte zrobienia źle”. Teza ta odbiła się echem u Ziga Ziglara w kilka dekad później: „Wszystko, co warto robić, warto robić kiepsko ... dopóki nie będziesz w stanie zrobić tego dobrze". Będąc z natury nieomal perfekcjonistą, nie lubię robić niczego, czego nie potrafię robić dobrze, więc rada ta jest skierowana właśnie do takich, jak ja. To, co prawdopodobnie miał na myśli Chesterton, przynajmniej tak, jak to rozumiem, to określenie: „niedoskonale” (raczej niż „kiepsko”). Nauczałem muzyki marnie; takoż nauczałem matematyki; łaciny nauczałem, jak ignorant. Jednak prawdopodobnie nauczałem takich rzeczy ... których nikt inny nie byłby w stanie nauczać. Uczyłem się w miarę nauczania; tak też czynili moi uczniowie.

Nauczałem rzeczy, których do końca nie rozumiałem - ale jeszcze raz powtórzę: Wiele jest rzeczy, których nie rozumiem do końca i prawdopodobnie nigdy nie zrozumiem. Mój dobry przyjaciel, Andrew Kern z Circe Institute, powiedział kiedyś: „Rozumienie jest wysoce przeceniane”. To mnie uwolniło. Chociaż prawdopodobnie nigdy w pełni nie zrozumiem Homera czy Hamleta, nie oznacza to, że czytanie, a nawet nauczanie o nich jest czymś, czego należy unikać lub czego trzeba się obawiać. Jestem obecnie świadom tego, że to właśnie dzięki jednoczesnemu nauczaniu i uczeniu się najlepszy rodzaj edukacji przytrafia się zarówno nauczycielowi, 
jak i uczniowi; uczą się zarówno nauczyciele, jak i uczniowie, a gdybyśmy mieli czekać, aż poczujemy się doskonale wykwalifikowani do nauczania, bardzo niewielu byłoby ludzi, którzy nauczaliby czegokolwiek. Niekiedy wystarczy być zwyczajnie o kilka kroków „do przodu”.

Ostatnim punktem w tym rozdziale jest to, że sposób uczenia się przez uczniów jest ostatecznie znacznie ważniejszy niż to, czego się oni uczą. Prawdopodobnie wszyscy doświadczyliśmy realizacji wymaganych przedmiotów, czytania podręczników do nich, robienia notatek na zajęciach czy zdawania egzaminów - może nawet dostając z nich piątki - i natychmiastowego zapominania dziewięćdziesięciu procent spośród treści, których rzekomo się nauczyliśmy. I na odwrót, prawdopodobnie wszyscy nauczyliśmy się bardzo wiele o czymś, co nas zainspirowało - nie dlatego, że było to wymagane, ale dlatego, że chcieliśmy to wiedzieć - rozwijając w ten sposób wytrwałość, a także umiejętności badawcze, organizacyjne i w zakresie prezentowania wiedzy, które przenieśliśmy we własną dorosłość jako wielkie beneficja.

Jeden przykład, który przychodzi mi tu na myśl, dotyczy nastolatków prowadzących debaty na temat polityki. Nieoczywiste sprawy, które dogłębnie badają (jak np. przepisy prawa dotyczące błędów w sztuce lekarskiej lub federalny wymiar sprawiedliwości w sprawach karnych) nie są same w sobie tak ważne jako tematy, jak motywacja do ich zgłębiania, często o rywalizacyjnej naturze, która pozwala im uczyć się tego, jak nauczyć się czegoś dobrze. A zanurzając się w jedną wąską dziedzinę wiedzy, uczą się też „spraw szkolnych” - słownictwa i gramatyki, faktów z historii, nauk przyrodniczych i ekonomii z nimi związanych.

Więc choć zgadzam się, że są pewne rzeczy, o których wszyscy uczniowie powinni mieć jakąś wiedzę (łacina, wiedza o społeczeństwie, ekonomia, literatura, historia), to jestem przekonany, że sposób, w jaki uczniowie studiują i uczą się ich, ma w rzeczywistości większą trwałość, a w konsekwencji jest ważniejszy niż szczegóły tego, czego się uczą.

\section{Lekcja 3: Każde dziecko jest różne od pozostałych}

Idea, że oto wszystkie dzieci są różne jest łatwa do upowszechniania. W rzeczywistości wszyscy to wiedzą. Dlaczego więc tak często konstruujemy szkoły i programy nauczania w sposób, w którym zakłada się, że wszystkie dzieci są takie same? Tak, niektóre czynniki wręcz wymagają podobieństwa: Wszystkie dzieci są wszak ludźmi. Wszystkie dzieci winny uczyć się kilku tych samych rzeczy. Wszystkie dzieci przechodzą przez te same etapy dorastania. Wszystko to prawda. Jednakże spójrzcie na schemat, w jaki szkoły są zasadniczo zmuszone przez swoją strukturę do nauczania dzieci w tym samym wieku, tych samych przedmiotów, według tego samego harmonogramu, a następnie do oceniania ich postępów przez porównywa- 
nie ich między sobą. A przecież to po prostu nie ma sensu. Dwie rzeczy doprowadziły mnie do tego w sposób bezdyskusyjny.

Pierwszą była moja praca z dziećmi z uszkodzeniem mózgu we wspominanych Instytutach w Filadelfii. Glenn Doman, jeden z ich założycieli, często wypowiadał następującą uwagę: „Każde dziecko ma uszkodzenie mózgu; to tylko kwestia lokalizacji i stopnia". Prawdą jest, że brzmi to trochę szorstko; Nikt nie chciałby niepełnosprawności dla swojego dziecka, jednak Doman przechodził dalej do wyjaśnienia: „Na jednym końcu spektrum jest neurologiczne funkcjonowanie całkowicie adekwatne, a na drugim śpiączka. Każde z nas jest gdzieś pomiędzy". Tak, to ma sens. A zatem, jeśli każdy z nas ma mózg nie całkiem doskonały, a tym, co stanowi różnicę, jest lokalizacja i stopień uszkodzenia, to możemy też rozumieć, że wszyscy możemy uczyć się na odmienne sposoby, w zależności od tego, czy nasze słabości są natury wzrokowej, słuchowej, dotykowej/kinestetycznej, lokomocyjnej itp. Bazując na tym spostrzeżeniu, wielu autorów i wykładowców próbowało skategoryzować style uczenia się - z lepszym lub gorszym skutkiem. A przecież dalej przeważnie trzymamy dzieci w podziale na grupy wiekowe, gdzie wszystkie robią to samo, według tego samego harmonogramu, choć być może w sposób nieco bardziej polisensoryczny. Aby instytucja oświatowa mogła zapewnić uczniom prawdziwie zindywidualizowaną edukację, musiałaby zmienić swoją tradycyjną strukturę i metodę - co jest nie tylko trudne do zrobienia, ale i z pozoru ryzykowne. Poznałem kilka szkół, którym udało się takie rozwiązania pomyślnie wprowadzić w życie, ale zdarza się to rzadko.

Jeszcze inną drogą, którą wyraziście dotarło do mnie, że każde dziecko jest inne, było nauczanie gry na skrzypcach. Naprawdę było to dla mnie najlepsze miejsce na rozpoczęcie kariery, ponieważ nauczyciele muzyki pracują zupełnie inaczej niż większość szkolnych nauczycieli. Po pierwsze, nie ma żadnego znaczenia, ile lat ma dziecko, kiedy zaczyna. Może rozpocząć lekcje w wieku czterech, dziesięciu, czternastu lub (jako człowiek dorosły) czterdziestu lat. Nigdy nie jest za późno, aby zacząć grać na instrumencie i chociaż pewne korzyści mogą tkwić w rozpoczynaniu gry w młodszym wieku, każdy wiek jest tu odpowiedni. Sam Suzuki zaczął grać na skrzypcach dopiero w wieku około dwudziestu lat. Nie ma takiego dekretu, wedle którego, z uwagi na to, że dziecko jest w pewnym wieku, musi zaczynać lekcje, bo inaczej będzie opóźnione. To ważna kwestia, ponieważ, podczas gdy niektóre dzieci mogą być gotowe i radzić sobie dobrze z lekcjami muzyki w wieku lat czterech, inne najwyraźniej nie, a zmuszanie ich do tego w zbyt wczesnym wieku może spowodować to, że będą je nienawidzić. Co oczywiste, jest to prawdą także w odniesieniu do takich rzeczy, jak czytanie, pisanie i matematyka, my jednakowoż nie myślimy o tej sprawie w podobny sposób, a nasze przepisy prawa stanowią, że wszystkie dzieci muszą rozpocząć naukę szkolną (a zatem dostosować się do państwowych „standardów") w wieku pięciu lub sześciu lat.

Drugim sposobem, w jaki nauczyciele muzyki kształcą uczniów o zróżnicowanych uzdolnieniach, jest rezygnacja z oczekiwania od nich szybkich postępów. 
Uczenie się wszystkich utworów z tomiku Nauka gry. Zeszyt $n r 1$ może zająć sześć miesięcy, ale może też zająć dwa lata. Ale to nie ma żadnego znaczenia. Liczy się to, że każdy uczeń robi postępy, uczy się utworów, rozwija technikę, kocha muzykę. Tylko to się liczy. Nie ma potrzeby porównywania uczniów między sobą, bo gdybyśmy to robili, mogłoby to przynieść bardzo negatywne skutki. W związku z tym nauczyciele muzyki nie wystawiają ocen. Jaki byłby ich sens? Czy ja, nauczyciel, powinienem usiąść na recitalu i oceniać moich uczniów tak, jakby to był egzamin końcowy? („Ups, przegapił tu C\# - 5-. Och nie, smyczkowanie nieodpowiednie - obniżamy do 4+. Aj! Poważne pominięcie - 3"). Co jest tutaj właściwe? Co robią nauczyciele muzyki zamiast tego? Zwracają uwagę na obszary, które wymagają modelowania i praktyki, a uczą tam, gdzie to potrzebne. Czyż szkoły nie byłyby zdrowszymi miejscami, gdyby nie zmuszano ich do grupowania uczniów według wieku, porównywania ich między sobą i kategoryzowania ich według wyników testów i ocen? Powiedziałbym, że tak, ale jak to osiągnąć, to jest wielkie pytanie. Stopniowo nauczyłem się eliminowania swoich oczekiwań opartych na wieku, unikania porównań jednych uczniów z innymi, ignorowania tego, czy moje dzieci są przed, czy za dziećmi innych ludzi, a w zamian przede wszystkim nauczyłem się stawiania pytania: „Czy one robią postępy?”, co tak naprawdę jest wszystkim, co ma znaczenie.

\section{Lekcja 4: „Progresywistyczna” edukacja nie oznacza postępu}

W 1990 r. Myra J. Linden i Arthur Whimbey napisali książkę zatytułowaną Dlaczego Jaś nie potrafi czytać: Jak polepszyć umiejętności w pisaniu, w której przedstawili dobrze udokumentowane badania, potwierdzające ich tezę, że umiejętności pisania absolwentów szkół średnich pogarszały się wówczas od dwudziestu lat. Raz jeszcze: To było w 1990 r. Nie znam ani jednej osoby, która chciałaby się spierać co do tego, że umiejętności w pisaniu uczniów szkół średnich poprawiły się od 1990 r., co może oznaczać, że owe umiejętności pisania stale się pogarszają od kolejnych, ponad dwudziestu lat. Dlaczego? Podczas kiedy niektórzy winiliby telewizję (a obecnie owe technologie, które odwracają uwagę wielu uczniów od czytania i pisania prawie wszystkiego, poza bzdurami), inni mogliby winić metodykę stosowaną do nauczania pisania lub powszechne ogłupianie, powodowane przez szkoły i programy nauczania. Niezależnie od przyczyn wiemy, że rządy i szkoły próbują zmienić ten stan rzeczy. Każda nowa mutacja „standardów kształcenia” wskazuje na podstawowe umiejętności: czytania, pisania i liczenia; wszystkie przynoszą w efekcie kolejną falę programów obiecujących rozwiązanie problemu. Ale tak się nie dzieje. Prawie pięć dekad upadku, a wszystko to w erze „progresywizmu”. Podobne uwagi można by poczynić w odniesieniu do umiejętności matematycznych i wiedzy ogólnej, a jednak eksperci ds. programów i dydaktyki wciąż przekonują 
nas, że nowe podejście z pewnością będzie lepsze. Ale nowe nie zawsze jest lepsze; czasami znajdujemy to, co działa lepiej, w tym, co było skuteczne w przeszłości.

Po zbadaniu obecnych mankamentów w nauczaniu pisania, Linden i Whimbey oferują dwie skuteczne strategie w tym zakresie, obie dawne i obie bardzo podobne do tego, co robimy w Instytucie na rzecz Doskonałości w Pisaniu4: 1) strukturalna analiza tekstu i 2) łączenie zdań. Cytują nawet (podobnie do mnie) autobiografię Franklina, w której mówi on o „robieniu krótkich uwag co do odczuć w każdym zdaniu”, a następnie o „ponownym uzupełnianiu wypracowań poprzez szczegółowe wyrażanie każdego wspomnianego odczucia". Wspominają oni też o Somerset Maughamie, który codziennie ręcznie kopiował fragmenty Biblii Króla Jakuba, „zapisując dla przyszłych zastosowań różne wersje fraz, które (go) uderzyły”, oraz o Malcolmie X, który będąc w więzieniu, wypisywał sobie słowa i definicje ze słownika, aby doskonalić swoje słownictwo i gramatykę. Podsumowując te kwestie, powiem, że proponowane przez przywoływanych autorów techniki nie są nowoczesne; są stare, a można je nawet prześledzić do czasów starożytnych i średniowiecza, kiedy to studiowanie retoryki zostało zbudowane na solidnym fundamencie zapamiętywania i naśladowania. Jednak współczesna, „progresywistyczna” edukacja odrzuciła to dziedzictwo jako nieefektywne, a nawet tłamszące kreatywność i motywację dziecka.

Lecz jeśli chodzi o nasze czasy, to wydaje się, że owa „postępowa” edukacja przechodzi w naprawdę przerażającą sferę - lekcji bez pisania wypracowań, z odrzuceniem wiedzy o faktach. Dwa lata temu, w 2016 r., wysłuchałem dr Sugaty Mitry, ówczesnego profesora technologii edukacyjnych na Uniwersytecie w Newcastle, który wygłosił wykład na konferencji Global Home Education w Rio de Janeiro, w ramach którego wspomniał o tym, że jego koledzy z uniwersytetu nie życzą sobie, by ich studenci korzystali ze smartfonów podczas egzaminów. „Zapytałem ich: Dlaczego nie?” - powiedział. Ich odpowiedź brzmiała: „Ponieważ odpowiedzieliby na każde pytanie”. Mitra replikował: „Ale czyż nie chcecie, aby odpowiedzieli na każde pytanie?" Następnie wypowiedział przepowiednię, że w końcu telefon skurczy się tak, aż zniknie w naszych ciałach i wówczas będziemy mieć ciągły dostęp do całej wiedzy ludzkości, a nasze prawnuki będą nam zadawać nie tylko pytanie: „Co to znaczy: 'kierować?” w odniesieniu do nieuniknionej wszechobecności pojazdów autonomicznych, bez kierowców, ale zapytają również: „Co to znaczy: 'uczyć się’?", w odpowiedzi na informację, że kiedyś ich rodzice i dziadkowie musieli zapamiętywać informacje i nosić je stale w swoich w głowach.

Chociaż my, tu obecni, moglibyśmy się z czegoś takiego pośmiać, to dr Mitra był całkowicie poważny. Wydaje się on być prawdziwym post-humanistą, który postrzega połączenie technologii z człowieczą naturą jako nieunikniony, kolejny krok w naszej „ewolucji”. Także i inni edukatorzy sprzeciwiają się obecnie nauczaniu dzieci „bezużytecznych” informacji - takich, jak znalezienie pierwiastka kwadratowego z danej liczby czy dat określonych wojen lub odkryć - jako zbędnych,

\footnotetext{
${ }^{4}$ IEW - Institute for Excellence in Writing, założony i prowadzony przez autora tekstu.
} 
ponieważ możemy je po prostu wygooglować lub zapytać Siri®1 lub Alexę®25. Konsekwencje nieznajomości rzeczy można jednak dostrzec poprzez swego rodzaju reductio ad absurdum. Osobną sprawą jest nieznajomość dat wojny secesyjnej i spytanie o to swojego telefonu, który powie: „To działo się od 11 kwietnia $1861 \mathrm{r}$. do 10 maja 1865 r.", jednakże trzeba wiedzieć, że w ogóle doszło do czegoś takiego jak owa wojna domowa, aby móc zadać to pytanie! Co się dzieje wtedy, gdy uczniowie znają tak mało faktów dotyczących historii lub polityki, że nie są zdolni nawet stawiać takich pytań?

Zamiast tego rozważmy argument Daisy Christodoulou (2014) z jej niezwykle ważnej książki pt. Siedem mitów na temat edukacji. Mit pierwszy brzmi: „Fakty uniemożliwiają zrozumienie”. To błędne przekonanie wywodzi się z prac „postępowca” J. J. Rousseau, który radził: „Nie udzielaj swemu uczniowi żadnych ustnych lekcji; powinien uczyć się wyłącznie na bazie doświadczenia" (to samo później mówił J. Dewey). W przeciwieństwie do tego zalecenia Christodoulou przedstawia przykład po przykładzie dla udowodnienia, że w pisaniu, matematyce i wszystkich pozostałych przedmiotach „(w)iedza i umiejętności są ze sobą powiązane. Postęp w zakresie danej umiejętności zależy od zgromadzonej wiedzy”. Zwraca ona też uwagę na to, że im więcej wiemy na dany temat, tym łatwiej jest go zrozumieć, a kończąc, stwierdza: „Poznanie takich faktów nie tylko nie wyklucza sensu całości, ale wręcz dopuszcza taki sens".

Technologia prowadzi do zaniku umiejętności, którą zastępuje. Pokażcie dzieciom, jak używać narzędzi do sprawdzania pisowni, a nie będą już dbać o jej reguły. Nauczcie je, jak korzystać z kalkulatorów, a nie będą wierzyć, że zapamiętywanie faktów matematycznych ma jakąkolwiek wartość. Pozwólcie im zadawać wszystkie pytania, jakie się w nich rodzą, swoim smartfonom, to nie uwierzą, że warto uczeniu się i zapamiętywaniu poświęcić choćby chwilę. Z żalem stwierdzić trzeba, że obecna „postępowa” edukacja jest do głębi skażona takim błędnym myśleniem. Obawiam się, że zanim zdamy sobie sprawę z rozmiarów wyrządzonych szkód, będzie za późno, aby uratować całe pokolenie z głębokiego bagna ignorancji i zależności od innych ludzi.

\section{Lekcja 5: „Gotowość do college’u i kariery”... też nie}

Gotowość do studiów i kariery. To wyrażenie, które jest już w powszechnym obiegu, spopularyzowało się, gdy Inicjatywa Państwowych Podstaw Programowych została przedyskutowana i przyjęta przez wiele państw pomiędzy 2009 a 2014 r. ${ }^{6}$ Sformułowanie to trafiło następnie do Wytycznych dla Egzaminów dla przeprojektowanego testu SAT - w czym nie ma niczego dziwnego, bowiem główny architekt

\footnotetext{
5 Siri®1 lub Alexa®2 to wirtualni asystenci użytkowników Internetu.

${ }^{6}$ Common Core State Standards - amerykańskie podstawy programowe.
} 
Common Core, David Coleman, został kolejnym prezesem College Board7 ${ }^{7}$ Sądzę, że dostrzegamy znaczącą różnicę pomiędzy tym, co może przetestować SAT a tym, czym jest prawdziwe przygotowanie do życia. Przebadałem sam tysiące osób na okoliczność takiego oto pytania: „Gdybyś był nauczycielem w college’u lub na uniwersytecie, który musi uczyć absolwentów szkół średnich, lub gdybyś był pracodawcą lub menedżerem, który musi zatrudniać absolwentów szkół średnich, jakich kompetencji byś od nich oczekiwał?” I wiecie co? Nikt nigdy nie odpowiedział: „Życzyłbym sobie takich ludzi, którzy wykazują się biegłością w czytaniu tekstu źródłowego wysokiej jakości i w sporządzaniu przekonującej i klarownej pisemnej analizy tegoż tekstu, popartej krytycznym rozumowaniem i dowodami zaczerpniętymi z tego właśnie źródła”. Zamiast tego zwykli ludzie najczęściej mówią: „Charakteru. Uczciwości”. „Pokory, zdolności do uczenia się nowych rzeczy”. „Energiczności, przejmowania inicjatywy”. „Postawy szacunku, umiejętności słuchania”, a nawet „Punktualności”. Po takich cechach ludzie przechodzą do spraw takich jak „Sprawna komunikacja” i „Umiejętność myślenia”. Wydaje się zatem zachodzić w tym odniesieniu rozdźwięk między tym, czego potrzebuje świat, a tym, co szkoły próbują robić dla przygotowania swoich uczniów na przyszłość. Oczywiście większość z tych niematerialnych wartości to kwestie charakteru wypracowywane przede wszystkim w domu i na zewnątrz szkoły. Są też one niemożliwe do oceny na podstawie testu wielokrotnego wyboru. Wielu rodziców i nauczycieli uważa szkolne przedmioty za najważniejszą rzecz w przygotowaniu dzieci do dorosłości, jednak z mojego doświadczenia wynika, że owe „szkolności” są prawdopodobnie najmniej ważną rzeczą w dojrzewaniu. Kolejne badania wykazują, że wyniki w nauce szkolnej mają niewielki wpływ na sukces i szczęście w późniejszym życiu, a my ciągle jednak utrzymujemy w sobie skłonność do niepokoju, a nawet stresu związanego ze szkolnymi sukcesami z okresu dzieciństwa.

Oczywiście nauka może i zwykle buduje charakter. Kumulatywne przedmioty, takie jak matematyka czy język obcy, wymagają konsekwentnego wysiłku przez długi czas, co nie tylko rozwija wytrwałość, ale i wzmacnia mózg, podobnie jak zapamiętywanie. Dodatkowo dobrze jest poznać trochę historii, geografii, nauk ścisłych i literatury, chociaż współczesne teksty i testy mogą zniekształcać lub wprowadzać chaos w szeregu faktów. Nie zrozumcie mnie, proszę, źle i nie zakładajcie, że nie dostrzegam wartości w wysiłkach edukacyjnych. Jest ich wiele.

Są jednak rzeczy ważniejsze w przygotowaniu się do dobrego życia niż oceny na świadectwach i wyniki testów. Jeśli będziemy pogłębiać rozumienie tego, jakie cechy charakteru, wartości i umiejętności życiowe warto, aby nasi uczniowie ponieśli ze sobą w dorosłość, to będziemy też w stanie podejmować najlepsze decyzje dotyczące wykorzystania naszego czasu i zasobów oraz naprawdę przygotować ich do studiów i kariery w sposób, jakiego College Board nigdy nie będzie w stanie zmierzyć.

\footnotetext{
7 College Board jest największą firmą organizującą w USA standaryzowane egzaminy o walorze maturalnym o nazwie SAT, których wyniki są akceptowane przez najważniejsze uczelnie wyższe (czynniki państwowe się tym nie zajmują).
} 


\section{Lekcja 6: Tak naprawdę chodzi o Was, nie o Nich/nie o Nie}

Jest takie stare powiedzenie: „Kiedy mama jest szczęśliwa, wszyscy są szczęśliwi”. Większość z nas zgodzi się, że jest w tym trochę prawdy. Proponuję dalszy ciąg: „Kiedy nauczyciel się uczy, wszyscy się uczą (a raczej prawie wszyscy)”. Uznajemy wszyscy i prawdopodobnie respektujemy banalny nieco termin „uczenie się przez całe życie”. Podczas gdy niektóre dziedziny wymagają częstego lub ciągłego rozwoju zawodowego, inne mogą nie wydawać się aż tak wymagające. Tak czy inaczej, nauczycielom lub rodzicom łatwo jest być zajętymi czym innym, z podzieloną uwagą lub zadowolonymi z własnej nauki.

W czwartym rozdziale Edukacji Tomasza Jeffersona, Oliver DeMille (2009) przedstawia siedem kluczy do wspaniałego nauczania opartych na metodach George'a Wythe, mentora Tomasza Jeffersona. Podczas gdy niektóre z nich są łatwe do zrozumienia („Klasyczne teksty w oryginale, nie podręczniki”), a inne są nieco enigmatyczne („Strukturyzuj czas, nie treści”), to ostatni „klucz”, numer siedem, uderzył we mnie, jak grom: „Ty, nie Oni/One”.

Jako nauczyciel gry na skrzypcach wiedziałem, jak ważne jest dla mnie utrzymanie własnego reżimu ćwiczeń - bez względu na to, jak miałoby to być niewygodne. Jako nauczyciel pisania zmuszam się teraz do pisania, kontynuowania nauki, czytania i stale uczę się czegoś więcej o historii i metodach tego, czego próbuję nauczać. To zapewnia mi świeżość, utrzymuje zaangażowanie moich uczniów i przygotowuje mój umysł i serce do przelewania ich zawartości w umysły i serca moich uczniów.

Tradycja naukowych urlopów dla wykładowców akademickich wygląda na słuszną, chociaż dla większości innych ludzi jest niepraktyczna. Mamy zadania do wykonania, rachunki do zapłacenia, dzieci do wyżywienia, projekty do wykonania, listy obowiązków do odhaczenia. Mamy naprawdę mnóstwo zajęć. A przecież może - to tylko domniemanie - moglibyśmy pracować lepiej i osiągać więcej, gdybyśmy zaplanowali czas na własną naukę. Być może od czasu do czasu, zwłaszcza w domu, powinniśmy wziąć sobie krótki urlop od nauczania. Zacząć czytać świetną książkę i zostawić dzieci samym sobie. Będą zdezorientowane. Być może dialog tutaj mógłby wyglądać mniej więcej tak:

„Mamo, czy nie powinniśmy zacząć się uczyć szkolnych rzeczy?”

- „Możesz, jeśli chcesz. Jestem zajęta”.

„Co robisz?”

- „Jestem zajęta. Zostaw mnie w spokoju”.

„Ale co ty robisz?”

- „Uczę się. Idź, rób coś swojego”.

„Och ... Czy nie powinniśmy zająć się jednak jakąś nauką?”

- „Tak, jak powiedziałam. Ty możesz, jeśli chcesz. Ale ja jestem zajęta”.

„Co czytasz?" 
- „Nie byłbyś zainteresowany”.

„Co mamy robić?"

- „Nie obchodzi mnie to”.

„Ale co czytasz?”

- „Słuchaj, jeśli chcesz tu zostać i być cicho, to przeczytam to na głos. W przeciwnym razie zostaw mnie w spokoju".

„No dobra ...”.

Jeśli jesteście głęboko zaangażowani w sprawy edukacji i zafascynowani swoją dyscypliną wiedzy, a wreszcie podekscytowani nowymi wyzwaniami, istnieje olbrzymia szansa, że wasi uczniowie przejmą od was taki entuzjazm. Jeśli zobaczą, że sam się uczysz i czerpiesz z tego przyjemność, mogą dać się zainspirować do samodzielnej nauki. Jeśli sam jesteś dobrym „uczniem”, prawdopodobnie będziesz miał też lepszych własnych uczniów. To prosta, choć trudna kwestia, co do której wielokrotnie przekonywałem się, że jest prawdziwą.

Kontynuowanie własnych studiów sprzyja również empatii. Łatwo jest zapomnieć, jak to jest, kiedy się nie wie czegoś, co się dobrze wiedziało, albo nie być w stanie łatwo zrobić czegoś, co zwykle robiło się z łatwością. Pracowałem kiedyś w szkole, która miała bardzo nietypową - a myślę, że rozsądną - politykę wobec wykładowców. Wszyscy nauczyciele i pracownicy administracji musieli co roku uczęszczać na jeden semestralny kurs z nowego dla siebie przedmiotu. Szkoła płaciła za te kursy, a nauczyciele wielokrotnie przypominali sobie, jak to jest być początkującym. Podobnie, słyszałem setki razy, jak uczestnicy moich seminariów pisarskich wyrażali empatię wobec swoich uczniów. „Wow, to nie jest takie proste, jak myślałem”. „Widzę, że potrzeba czasu, aby zrobić to dobrze”. „Myślę, że moje oczekiwania były nieco na wyrost”. A nawet: „Teraz rozumiem, dlaczego mój syn płacze, kiedy musi coś pisać". To wszystko są bardzo ważne prawdy, które docierają do nas w chwilach uważności, a potem znowu wpadamy na nie w miesiąc, i w rok później.

\section{Lekcja 7: Miłość jako kluczowa kwestia}

Wszyscy wspaniali nauczyciele, których spotkałem, kochali nie tylko swoje przedmioty studiów, ale także swoich uczniów. To rzecz uniwersalna. Gdy spoglądam wstecz, przypominam sobie bardzo niewielu nauczycieli z moich klas czy szkół, jednak ci, którzy na stałe są w mojej w pamięci, są nimi nie z powodu tego, czego mnie nauczyli, ale dlatego, że mnie darzyli życzliwością. Pani Berry, moja nauczycielka w piątej klasie, nie była wyższa niż najwyższe dziecko w naszej klasie. Była drobna, ale zorganizowana i surowa, świetnie się bawiła na boisku do gry w dwa ognie podczas przerw i prawdziwie mnie kochała - wiedziałem o tym. Prawdopodobnie kochała wszystkich swoich uczniów, ale ja wiedziałem, że kocha mnie. Pan 
Grantham, mój nauczyciel orkiestry w gimnazjum, zajmuje miejsce w mojej zacierającej fakty pamięci ani nie dlatego, że rzucał ołówkami w tych uczniów, którzy byli nieuważni, ani wskutek tego, że robił śmieszne miny, mówiąc przy tym zabawnymi głosami, ale dlatego, że był prawdziwym motywatorem. Wierzył we mnie osobiście i wydobył ze mnie moje najwartościowsze wysiłki. On mnie zwyczajnie kochał. Spośród wielu nauczycieli liceum, których miałem, tylko dwoje przypominam sobie z nazwiska: Panią Harper, nauczycielkę łaciny, która była urocza, i pana Spurgeona, który uczył angielskiego. Kochał on swoje wiersze, kochał swoje książki i uwielbiał uczyć nas tego, co kochał. Nie pamiętam ani jego wierszy, ani opowiadań, ale pamiętam jego zapał.

Jako dorosły miałem czterech wielkich mentorów: dr. Shinichi Suzukiego, dr. Glenna Domana, Panią Annę Ingham i dr. Bertina Webstera, o których napisałem więcej w artykule pt. $Z$ perspektywy czasu: Bohaterowie Opatrzności. Chociaż czas, który z nimi spędziłem, i edukacja, jaką mi zapewnili, były przełomowe dla mojej misji, to jednak to coś, co uczyniło ją tak silną, a wręcz zmieniającą moje życie, to był fakt, że oni mnie kochali. Nie tylko miłością ludzkości, ale osobistą, szczerą miłością - oni mnie docenili, wierzyli we mnie i ufali mi. Chociaż wiem, że ci wielcy mentorzy kochali innych tak samo jak mnie, to zawsze czułem się indywidualnie kochany i motywowany do działania, i to właśnie stanowi dla mnie różnicę.

Już w początkach swojej kariery nauczycielskiej odkryłem fakt, że jeśli moi uczniowie czują się kochani i doceniani, jeśli wiedzą, że ich lubię i jestem szczęśliwy $\mathrm{z}$ przebywania $\mathrm{z}$ nimi, to wszystko idzie dobrze. Uczniowie $\mathrm{w}$ różnym wieku, przeważnie od szóstego do trzynastego roku życia, którzy mieli przychodzić do mojego studia skrzypcowego w godzinach pozalekcyjnych, byli często zmęczeni lub nieskoncentrowani. Wiedziałem, że zanim jeszcze wyjmiemy skrzypce, muszę im zakomunikować swoją miłość do nich. Ale jeśli jesteś dwudziestokilkuletnim nauczycielem-mężczyzną, rzeczą której nie wolno ci mówić dwunastoletniej dziewczynce, jest: „Cześć, kochanie. Tak się cieszę, że tu jesteś, bo tak bardzo cię kocham”. Nie. Musisz znaleźć inne sposoby wyrażania swojego uczucia. I dlatego właśnie opracowałem kilka patentów sekretnej broni.

Jedną z tych technik jest coś, o czym prawdopodobnie już słyszeliście: „napełnianie emocjonalnego zbiornika paliwa” lub „wkłady na emocjonalne konto bankowe”. Bardziej podoba mi się pomysł konta bankowego, ponieważ metafora zbiornika paliwa sugeruje, że należy go napełnić, aby go następnie opróżnić. Mój nauczyciel, dr Suzuki, wykorzystał ideę konta bankowego, ale z drobną modyfikacją - „Żyj z odsetek!". Trzeba rozumieć, iż jednym z problemów w nauczaniu gry na skrzypcach jest to, że jak tylko ktoś podnosi skrzypce, to robi wszystko źle. Nauczanie jest ciągłym procesem korygowania, a większość ludzi nie znosi dobrze bycia stale poprawianym. Postępowałem więc zgodnie z modelem Suzukiego. Zawsze mówił najpierw coś pozytywnego, czasem nawet kilka przyjemnych rzeczy, zanim dokonał pierwszej korekty. Pamiętam szczególnie jeden przypadek. Nowy nauczyciel zagraniczny przyjechał na kilka miesięcy do Matsumoto. Kiedy osoba ta po raz 
pierwszy grała dla Suzukiego w klasie mistrzowskiej, my, bardziej doświadczeni nauczyciele-stażyści, wzdrygaliśmy się co chwila i wstrzymywaliśmy wspólnie oddech, ponieważ gra tego młodego człowieka była zwyczajnie straszna - niedostrojona, z nieodpowiednimi rytmami i smyczkowaniem, z okropnym tonem. Człowiek ten był zupełnie nieprzygotowany. Co zrobił Suzuki? Cóż, pierwsza opinia, jaka wyszła z jego ust, brzmiała: „Dobrze. Możesz grać”. Następnie zaś dał nowemu krótką lekcję tego, jak prawidłowo trzymać smyczek. Nieco później kilkoro z nas wdało się w dyskusję o tym wydarzeniu.

„Jak Sensei mógł powiedzieć, że on grał dobrze?” zapytał jeden.

Jeden ze starszych stażem odrzekł: „Sensei nie powiedział, że gra dobrze. Powiedział: „Dobrze. Możesz grać”. To co innego.

To był punkt wyjścia. Zaczął od pozytywnego stwierdzenia. Pewnego razu Suzuki podzielił się z nami swoją strategią. Wyjaśnił, że trzeba nam „żyć z odsetek”. Wpłać wystarczającą ilość miłości na emocjonalne konto bankowe ucznia, by kiedy dokonasz wypłaty, nakazując poprawki lub będąc surowym, nadal mieć na nim dodatkowy kapitał, dający odsetki tak, aby przyszłe poprawki nie wyczerpały u tego ucznia zasobów do tego stopnia, że znienawidzi lekcje i zechce je porzucić.

Nabrałem więc nawyku mówienia pozytywnych rzeczy, nawet liczenia ich na palcach, aby mieć pewność, że przed pierwszą poprawką poczyniłem dziesięć dobrych komentarzy. „Witaj, dzięki za przybycie na czas! Naprawdę to doceniam, bo wiem, jak ciężko jest moim dzieciom przekonać swoją mamę, żeby zaprowadziła je na zajęcia na czas”. „Masz na sobie śliczny strój” (tak naprawdę nie znam się na tym, czy to doprawdy śliczne, ale wiem z pewnością, że dwunastoletnia dziewczynka mogła spędzić i pół godziny, próbując wymyślić, w co się ubrać tego ranka). „Twoje skrzypce są ładne i czyste. Dobrze jest utrzymywać swój instrument w czystości" (choć może akurat to dziecko nie ćwiczyło przez cały tydzień i dlatego był czysty). Oczywiście nie mówię, żeby dawać nieszczere pochwały. Mówię tylko: Znajdźcie rzeczy warte pochwały. To naprawdę działa.

Drugą sekretną bronią, którą odkryłem, jest siła uśmiechu. Uśmiech komunikuje wszystko, co właściwe: Lubię cię. Cieszę się, że tu jesteś. Jestem ci wdzięczny. Chociaż niektórzy uważają, że uśmiech jest wynikiem specjalnego nastawienia, ja odkryłem, że to uśmiech wpływa na postawy. W swoich wczesnych latach miałem zwyczaj ćwiczyć w lustrze uśmiechy wszelkiego rodzaju - szerokie, drobne, pokojowe, zdumione, subtelne, dramatyczne - a następnie wypróbowywałem je na swych uczniach. Nie robię już tego więcej, choć dysponuję już przyzwoitym repertuarem (lub arsenałem, w zależności od sytuacji).

Pewne doświadczenie razu pewnego zmieniło moje życie na zawsze. Byłem na lotnisku w Spokane, wyjeżdżając na sześć dni na warsztaty pisania do Boise, kiedy moja córeczka Fiona akurat zaczęła to przeżywać.

„Tatusiu, czy naprawdę musisz znowu jechać? Tak bardzo za tobą tęsknię, kiedy cię nie ma". I w szloch. 
Moje ojcowskie serce pękało z bólu, ale zobowiązanie to zobowiązanie, no i to była przecież moja praca. Ale, pomyślałem sobie, dlaczego nie miałbym jej zabrać ze sobą? Bilet ze Spokane do Boise nie kosztuje wcale tak wiele. Wykonałem telefon.

- „Dobrze. Chcesz jechać ze mną?”

„Naprawdę?"

- „Pewnie. Kupimy zaraz bilet, potem trochę ciuchów, a także szczoteczkę do zębów w Walmarcie i będziesz mogła spędzić ze mną tydzień w Boise”.

Chociaż moja żona rzuciła mi sceptyczne spojrzenie, wiedziałem, że mogę sprawić, by to naprawdę zadziałało. I tak się też stało. Polecieliśmy do Boise, a następnego dnia pozwoliłem jej usiąść na warsztatach z pisania dla grupy uczniów z klas od III do V. Nigdy wcześniej czegoś tego nie robiła, będąc trochę za małą. Nie jestem pewien, co robiła na tych zajęciach, ponieważ byłem bardzo zajęty pomaganiem dzieciom innych rodziców. Po zajęciach pojechała bawić się z dziećmi rodziny, z którą to umówiłem, a ja poprowadziłem jeszcze dwa kolejne spotkania. Odebrałem ją wieczorem, a kiedy jechaliśmy do hotelu, zapytałem:

- „I co Fiona, jak ci się podobają lekcje pisania?”

A ona, z dziecięcym podziwem dla kogoś, kto jest dlań idolem, westchnęła:

„Och tato, to było po prostu cudowne”.

- „Jestem gość" - pomyślałem o sobie. A wtedy ona powiedziała to coś, co zmieniło moje życie.

„Tatusiu, dlaczego nie jesteś taki sam w domu?”

I w tym momencie uświadomiłem sobie, jak łatwo jest mi być bezwarunkowym entuzjastą wobec innych, podekscytowanym, pomocnym i szczęśliwym w otoczeniu dzieci innych ludzi, i jak łatwo zapominam o tym, by być takim w stosunku do własnych dzieci (Tak, tak, ja kocham ciebie, a ty mnie, wiemy o tym dobrze oboje, ale czy teraz możesz już pójść do swoich zajęć? Oboje mamy ważne rzeczy do zrobienia!). Od tego dnia nieodwołalnie postanowiłem wyrażać swoją miłość tak samo wobec własnych dzieci, uczących się w edukacji domowej, jak wobec wielu uczniów w ramach moich zajęć i warsztatów. Miłość rzeczywiście jest tutaj kluczem.

I takich jest właśnie kilka rzeczy spośród tych, których nauczyłem się w trakcie trzech dekad mojego nauczycielstwa. Wątpię, czy czeka mnie jeszcze kolejnych trzydzieści lat, ale spodziewam się, że będę trwać przy uczeniu się nowych prawd podczas swego nauczania i nauczaniu tego, czego się sam uczę. Żyję wspaniałym życiem. I jestem za to głęboko wdzięczny. Wszystkie moje dzieci są dziś dorosłe i żyją już na swoim, co jest dość dziwnym odczuciem. Ale mam małe wnuki, mieszkające drzwi w drzwi, a drugie niedaleko od nas i wręcz nie mogę się już doczekać dnia, który nie jest zbyt odległy od dziś, kiedy jedno lub dwoje z nich będzie uczęszczać na „zajęcia z pisania u Pana Pudewy”. Jak się spodziewam, także i one nauczą mnie jakiejś prawdy lub dwóch. 


\section{Bibliografia}

Christodoulou D. (2014) Seven Myths about Education, London, Routledge.

DeMille O. (2009) A Thomas Jefferson Education, TJED.org

Gatto J. T. (1992) Dumbing Us Down. The Hidden Curriculum of Compulsory Schooling, Gabriola Island, New Society Publishers.

Linden M. J., Whimbey A. (1990) Why Johnny Can't Write: How to Improve Writing Skills, London, Routledge. 